CLINICAL STUDY

\title{
Germline VHL gene mutations in Hungarian families with von Hippel-Lindau disease and patients with apparently sporadic unilateral pheochromocytomas
}

\author{
Peter Gergics, Attila Patocs ${ }^{1}$, Miklos Toth, Peter Igaz, Nikolette Szucs, Istvan Liko ${ }^{2}$, Ferenc Fazakas ${ }^{3}$, Istvan Szabo ${ }^{4}$, \\ Balazs Kovacs ${ }^{4}$, Edit Glaz and Karoly Racz \\ 2nd Department of Medicine, Faculty of Medicine, Semmelweis University, 46 Szentkirályi Street, Budapest H-1088, Hungary, ${ }^{1}$ Molecular Medicine \\ Research Group, Hungarian Academy of Sciences and Semmelweis University, 9 Roosevelt Square, Budapest H-1051, Hungary, ${ }^{2}$ Gedeon Richter Ltd, \\ 19 Gyomroi Street, Budapest H-1103, Hungary, ${ }^{3}$ Medical and Health Science Center, University of Debrecen, 98 Nagyerdei Street, Debrecen H-4012, \\ Hungary and ${ }^{4}$ Regional University Centre of Excellence in Environmental Industry Based on Natural Resource, Szent Istvan University, 1 Pater Karoly \\ Street, Godollo H-2103, Hungary \\ (Correspondence should be addressed to K Racz; Email: racz@bel2.sote.hu)
}

\begin{abstract}
Objective: Von Hippel-Lindau (VHL) disease is a hereditary tumor syndrome caused by mutations or deletions of the VHL tumor-suppressor gene. Germline VHL gene alterations may be also present in patients with apparently sporadic pheochromocytoma (ASP), although a wide variation in mutation frequencies has been reported in different patient cohorts.

Design: Herein, we report the analysis of the VHL gene in Hungarian families with VHL disease and in those with ASP.

Methods: Seven families ( 35 members) with VHL disease and 37 unrelated patients with unilateral ASP were analyzed. Patients were clinically evaluated and the VHL gene was analyzed using direct sequencing, multiplex ligation-dependent probe amplification, and real-time PCR with SYBR Green chemistry. Results: Disease-causing genetic abnormalities were identified in each of the seven VHL families and in 3 out of the 37 patients with ASP (one nonsense and six missense mutations, two large gene deletions and one novel 2 bp deletion). Large gene deletions and other genetic alterations resulting in truncated VHL protein were found only in families with VHL type 1, whereas missense mutations were associated mainly, although not exclusively, with VHL type 2B and type 2C.

Conclusions: The spectrum of VHL gene abnormalities in the Hungarian population is similar to that observed in Western, Japanese, or Chinese VHL kindreds. The presence of VHL gene mutations in 3 out of the 37 patients with ASP suggests that genetic testing is useful not only in patients with VHL disease but also in those with ASP.
\end{abstract}

European Journal of Endocrinology $161495-502$

\section{Introduction}

Von Hippel-Lindau (VHL, OMIM No. 19330) disease is a rare, dominantly inherited, multisystem family tumor syndrome caused by mutations or deletions of the VHL tumor-suppressor gene mapped to chromosome locus 3p25-26 (1). Patients with VHL disease are at risk for the development of retinal, cerebellar, spinal and, less frequently, pancreatic, renal, pulmonary, liver, and adrenal hemangiomas/hemangioblastomas (2-4); clear-cell renal carcinomas, pheochromocytomas, endolymphatic sac tumors, multiple renal, epididymal and pancreatic cysts; cystadenomas of the epididymis and the broad ligament, and pancreatic islet cell tumors $(1,5,6)$. VHL disease has been divided into two main groups; patients with type 1 disease have a greatly reduced risk of pheochromocytomas, but can develop all the other manifestations of the disease, whereas patients with VHL type 2 have pheochromocytomas. Type 2 families may have either a low (type 2A) or high risk (type $2 \mathrm{~B}$ ) for renal cell carcinoma. VHL type $2 \mathrm{C}$ is a separate entity in which affected patients have pheochromocytomas without other manifestations of the disease (7).

The VHL gene encodes two different protein isoforms due to the use of two translation initiation sites; the larger protein (pVHL30) consists of 213 amino acids, whereas the smaller pVHL19 contains residues 54-213 of the pVHL30. The pVHL19 shows a high homology among human, dog, mouse, and rat $(1,8,9)$, and it has all the functional domains of the pVHL30 (9-11). The protein model of pVHL19 published in 1999 by Stebbins et al. contains two functional subdomains; a smaller, helical $\alpha$-domain (residues 155-192), which consists of three helices (H1, H2, and H3), and a larger $\beta$-domain 
(residues 63-154 and residues 193-204), which forms a seven-stranded $\beta$ sandwich and an $\alpha$ helix (H4). For VHL protein function, two important sites have been identified; one of them represents the elongin C-binding site (amino acid residues 157-170) and the other is the hypoxia-inducible factor $1 \alpha$ (HIF $1 \alpha)$-binding site (amino acid residues $91-113$ in $\beta$-domain) (12). The majority of disease-causing VHL gene mutations are located in one of these two binding sites.

More than 900 different mutations of the VHL gene have been described (http://www.umd.be/) (13). The majority of VHL type 1 cases are caused by missense mutations affecting the hydrophobic core of the protein, by mutations resulting in truncated protein, and by partial gene deletions, which cause a complete defect of protein function. By contrast, VHL type 2 is usually associated with missense mutations affecting the protein-binding sites of the VHL protein. To date, only a few mutations upstream of the internal start codon 54 have been described (codons 25, 38, 46, and 52), and these mutations have been associated either with pheochromocytomas (codons 25 and 38) or with VHL disease (codons E46X and E52K) (14-17).

VHL disease has an approximate incidence of 1/36000 live births (18), and germline VHL gene mutations have been found in about $40 \%$ of familial or bilateral pheochromocytomas $(19,20)$. Screening for germline VHL gene mutations may also be recommended in patients with apparently sporadic unilateral pheochromocytomas, although a wide variation in mutation frequencies ranging from 0 to $11 \%$ in different patient cohorts has been reported (19-22). The identification of germline VHL gene mutations in patients with apparently sporadic pheochromocytomas (ASP) appears to be important, as the onset of the VHL disease may show a high variability and many patients with VHL-related pheochromocytomas may carry a high risk for developing other manifestations of the disease.

In this study, we present the results of germline mutation analysis of the VHL gene in Hungarian families with VHL disease and patients with apparently sporadic unilateral pheochromocytomas.

\section{Subjects and methods}

\section{Families with VHL disease}

A total of 35 members from seven unrelated families with VHL disease were evaluated. Initial screening included medical history, physical examination, abdominal ultrasonography, computed tomography (CT) or magnetic resonance imaging (MRI), brain and spinal cord MRI, ophthalmologic examination, and laboratory tests, which included routine biochemical testing and $24 \mathrm{~h}$ urinary catecholamine metabolite determination. All patients with VHL disease and family members of patients who proved to have VHL gene mutations underwent genetic counseling, and clinical as well as genetic screening was performed in all relatives who agreed to the screening tests. After genetic screening, all index patients were reinvestigated for VHL-related tumors, but no newly detected tumors were found. Clinical findings are summarized in Table 1.

In family $\mathrm{A}$, the index patient was a woman who had multiple (occipital, parietal, and cerebellar) hemangioblastomas, renal cysts, and retinal hemangiomas. The parents and one of the two children of the index patient had no clinical symptoms, whereas in the other child retinal hemangiomas were diagnosed at the age of 6 years.

In family B, the index patient was a young man who developed retinal hemangiomas at the age of 19 years, and cerebellar hemangioma as well as renal and pancreatic cysts at the age of 27 years. A moderate erythrocytosis with normal white blood cell and platelet count was also observed. The parents of the patient rejected clinical and genetic screening, whereas clinical screening in a younger brother of the index patient revealed no abnormality.

In family $C$, the index patient was a man. He was operated for cerebellar hemangioblastoma at the age of 33 years. Preoperative clinical screening also showed renal cysts. Two years later, a pancreatic cyst and bilateral renal cell carcinomas were found and the patients underwent bilateral nephrectomy with subsequent chronic hemodialysis. Family members were not available for clinical and genetic screening except a brother whose screening revealed no abnormality.

In family D, the index patient was a young woman who underwent surgery for cerebellar hemangioblastoma at the age of 22 years. Multiple renal cysts and retinal detachment with vitreous hemorrhage were also observed. At the age of 26 years, pancreatic cyst, spinal cord hemangiomas, and recurrence of the cerebellar lesion were found. Family members were not available for clinical and genetic screening, but family history revealed that the patient's father died of metastatic renal cell carcinoma.

In family E, the index patient was a 21-year-old man who had bilateral highly vascularized renal masses and a large number of renal cysts. Family history indicated a high suspicion for VHL disease, as his mother was operated for renal cell carcinoma, his uncle had spinal cord tumor, and his grandmother underwent operation for renal cell carcinoma. However, detailed clinical evaluation could not be performed in family members.

In family $\mathrm{F}$, the index patient was a man who developed retinal hemangiomas and unilateral pheochromocytoma at the age of 27 years. Abdominal CT showed also horseshoe kidneys. His mother underwent operation for renal cell carcinoma at the age of 49 years, but other manifestations of the VHL disease were absent during her regular follow-up. 


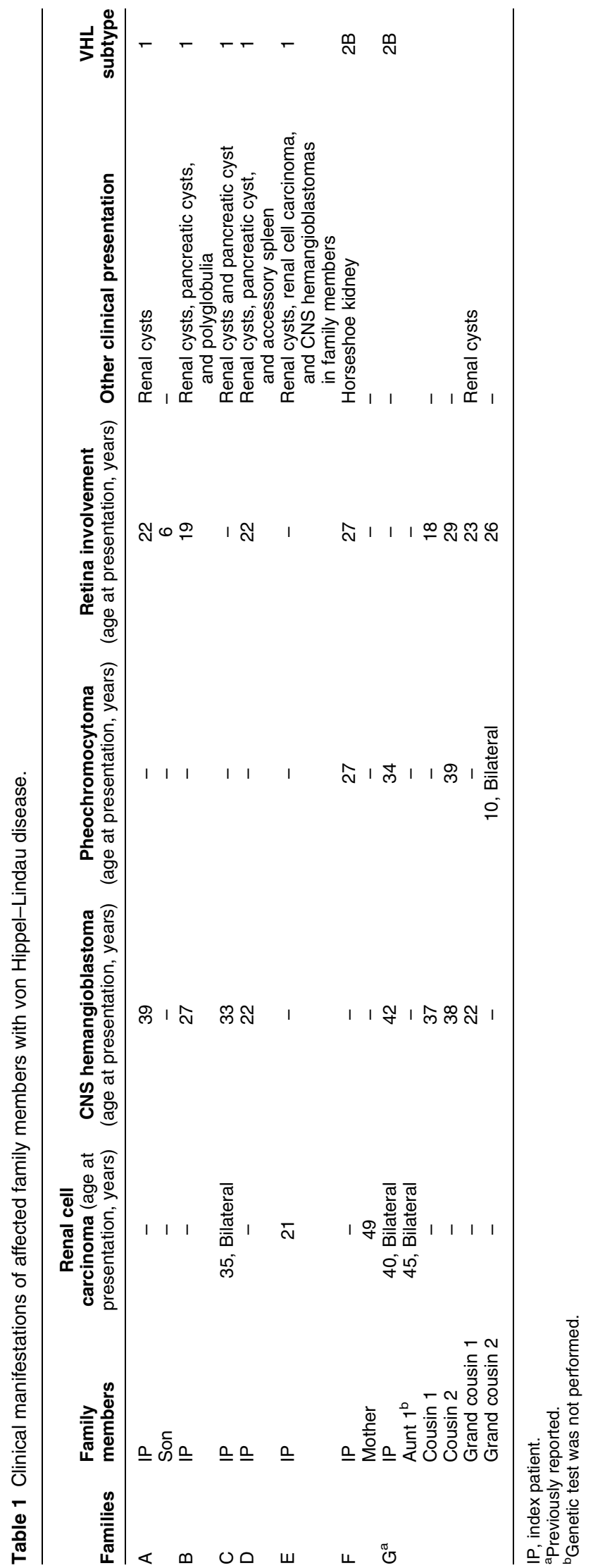

Family G was a large VHL family spanning five generations (23). The index patient was a woman who was operated for pheochromocytoma and renal cell carcinoma diagnosed at the age of 34 and 40 years respectively. She also developed spinal cord, cerebellar, and medulla oblongata hemangioblastomas at the age of 42 years. Her parents showed no clinical, biochemical, or radiological evidence of the disease, but VHL-associated tumors were detected in five other family members (bilateral renal cell carcinomas in one, renal cysts in one, spinal cord, cerebellar, and medulla oblongata hemangioblastomas in three, retinal hemangioblastomas in four, and pheochromocytomas in two family members).

\section{Patients with ASPs}

The study included 37 unrelated patients with histologically confirmed, apparently sporadic unilateral pheochromocytomas evaluated at the 2nd Department of Medicine, Faculty of Medicine, Semmelweis University between 1998 and 2008. There were 17 men (age, mean \pm s.D. $40.6 \pm 15.4$; range, 12-67 years) and 20 women (age, mean \pm s.D. $37.7 \pm 14.4$; range, 19-63 years). Patients with bilateral and familial pheochromocytomas and those with personal or family history of syndromic disease (VHL, MEN2, neurofibromatosis type 1 (NF1), and familial paraganglioma syndromes) were excluded. Preoperative evaluation included medical history, physical examination, abdominal ultrasonography, CT or MRI, MIBG-scintigraphy, ophthalmologic examination, routine biochemical testing, and $24 \mathrm{~h}$ urinary catecholamine metabolite determination. Patients who proved to have VHL gene mutations underwent genetic counseling, and clinical screening for other VHL-associated tumors was performed. Genetic and clinical screening for VHL-associated tumors was also offered for relatives of mutation positive patients.

\section{Genetic screening for VHL gene mutations}

Written informed consent was obtained from all patients and family members who participated in the study. Genomic DNA was extracted from peripheral blood leukocytes using DNA isolation kit for mammalian blood (Roche Diagnostics $\mathrm{GmbH}$ ). Mutation analysis of splice sites and exons 1,2 , and 3 of the $V H L$ gene was performed by using direct sequencing of DNA samples amplified by PCR. PCR amplifications were carried out using modified oligonucleotide primers (24), which covered the exon-intron boundaries. Sequence analysis was performed by direct cycle sequencing using the SequiTherm Excel II DNA Sequencing Kit-LC (Epicentre Technologies, Madison, WI, USA) and an automated Li-COR IR2 sequencer (Li-COR Inc., Lincoln, NE, USA) or by direct cycle sequencing using the Big Dye Terminator Cycle 
Sequencing kit v3.1 (Applied Biosystems, Foster City, CA, USA), and run on an automated sequencer 310 Genetic Analyzer from Applied Biosystems.

In cases when direct sequencing failed to show VHL gene mutations, DNA samples were analyzed for germline deletion of the VHL gene. A nonsequencespecific real-time detection of PCR products was performed by using the DNA binding dye SYBR Green I, as described by Ponchel et al. In a final volume of $25 \mu \mathrm{l}, 120 \mathrm{ng}$ DNA was amplified with Power SYBR Green PCR Master Mix (Applied Biosystems) using highly specific primer pairs (12.5 pg each) for flanking exons of the VHL gene. Exon 8 of the glyceraldehyde-3phosphate dehydrogenase gene $(G A P D H, 12 \mathrm{p} 13)$ was used as a reference in simultaneous co-amplification. The Applied Biosystems 7500 Fast Real-Time PCR System was used for absolute quantitation. All reactions were performed in triplicates, and comparative threshold $\left(C_{t}\right)$ values were accepted if the S.D. was lower than 0.05. The $\Delta C_{\mathrm{t}}$ values $\left(C_{\mathrm{t}}(\mathrm{vhl}\right.$ exon $)-$ $\left.C_{\mathrm{t}}(\mathrm{GAPDH})\right)$ were calculated for the average of each triplicate. A $\Delta C_{\mathrm{t}}$ of 0 indicated a ratio $(R)$ of 1 between the target and the reference $\left(2^{-\left(\Delta C_{\mathrm{t}}\right)}=2^{0}=1\right)(25)$. Controls included samples from patients with known heterozygous VHL gene alterations and those from healthy subjects. The cut-off value of the ratio for submitting the absence of an exon of the VHL gene was 0.6. All primer sequences are available on request. Primers were purchased from Invitrogen Life Technologies. The specificity of all primers was checked using NCBI-BLAST (http://www.ncbi.nlm.nih. gov/BLAST/).

Large deletions of the VHL gene were also analyzed using multiple ligation-dependent probe amplification according to the manufacturer's instructions (MRCHolland, Amsterdam, The Netherlands) (26). 6-FAMlabeled fragments were separated using capillary electrophoresis $(310$ Genetic Analyser from Applied Biosystems). The relative peak areas were compared according to the manufacturer's instructions. Deletions were established if reductions in relative peak areas were
$<55 \%$ compared with controls. Control samples were obtained from individuals with known heterozygous VHL gene alterations (mutation or polymorphism).

\section{Results}

VHL gene mutations or deletions were identified in all index patients with VHL disease as well as in several other members of our VHL families (Table 2). In family A, a previously described disease-causing heterozygous L158V mutation was found in the index patient and in one of the two children who had retinal hemangiomas. This mutation developed de novo in the index patient, as it was absent in the two parents. Repeat clinical evaluation of the affected son of the index patient revealed no other VHL-related tumors. The index patient of family $\mathrm{B}$ proved to have a heterozygous R161X mutation, which has been already published in VHL families. This mutation was absent in one clinically healthy brother of the index patient, while other members of this family were not available for genetic screening. The index patient in family $\mathrm{C}$ proved to have a heterozygous deletion of exon 3 of the VHL gene, which was absent in a clinically healthy brother of the index patient. In family D, the index patient had several manifestations of the disease, including retinal detachment with vitreous hemorrhage that is known to be closely associated with the presence of hemangiomas (27). The patient had a heterozygous deletion of exon 2 of the VHL gene; genetic screening could not be performed in other members of this family. The index patient was also the only member available for genetic screening in family $\mathrm{E}$ who had a previously unpublished heterozygous 2 bp deletion in exon 2 of the VHL gene (354_355delCT). In family F, genetic analysis showed the presence of a previously described diseasecausing heterozygous $\mathrm{R} 167 \mathrm{Q}$ mutation in the index patient and in his mother, both clinically affected with VHL disease. In family G, a previously described diseasecausing heterozygous S80I was identified in the index

Table 2 Characteristics of the VHL gene mutation identified in patients with von Hippel-Lindau disease and in those with apparently sporadic pheochromocytomas.

\begin{tabular}{|c|c|c|c|c|c|c|}
\hline Families & VHL genotype & $\begin{array}{l}\text { Location within } \\
\text { the } V H L \text { gene }\end{array}$ & $\begin{array}{l}\text { Number of genetically } \\
\text { tested/number of } \\
\text { mutation carriers }\end{array}$ & $\begin{array}{l}\text { Number of clinically } \\
\text { asymptomatic } \\
\text { mutation carriers }\end{array}$ & $\begin{array}{l}\text { Domain of } \\
\text { VHL protein }\end{array}$ & $\begin{array}{l}\text { VHL } \\
\text { phenotype }\end{array}$ \\
\hline$A$ & L158V & Exon 3 & $6 / 2$ & 1 & $\alpha$ & 1 \\
\hline B & R161X & Exon 3 & $2 / 1$ & 0 & $\alpha$ & 1 \\
\hline C & Exon 3 deletion & Exon 3 & $2 / 1$ & 0 & $\alpha$ and $\beta$ & 1 \\
\hline D & Exon 2 deletion & Exon 2 & $1 / 1$ & 0 & $\beta$ & 1 \\
\hline $\mathrm{E}$ & 354_355delCT & Exon 2 & $1 / 1$ & 0 & $\alpha$ and $\beta$ & 1 \\
\hline $\mathrm{F}$ & $\mathrm{R} 167 \mathrm{Q}$ & Exon 3 & $2 / 2$ & 0 & $\alpha$ & $2 \mathrm{~B}$ \\
\hline $\mathrm{G}$ & S801 & Exon 1 & $21 / 7^{a}$ & 2 & $\beta$ & $2 \mathrm{~B}$ \\
\hline ASP & L63P & Exon 1 & $5 / 3$ & 2 & $\beta$ & $2 \mathrm{C}$ \\
\hline ASP & Y156C & Exon 3 & $2 / 1$ & 0 & $\beta$ & $2 \mathrm{C}$ \\
\hline ASP & R167G & Exon 3 & $4 / 1$ & 0 & $\alpha$ & $2 \mathrm{C}$ \\
\hline
\end{tabular}

ASP, apparently sporadic pheochromocytoma; VBC, VHL/elongin B/elongin C complex.

${ }^{a}$ Genetic test was not performed in one clinically affected family member. 
patient and in five other family members affected with VHL disease, as well as in two clinically healthy family members. Repeat clinical evaluation of family members who carried the mutation showed no newly developed VHL-related tumors. Some members of this family also had the P25L variant of the VHL gene, (rs35460768; dbSNP127), but this proved to be a neutral variant (23).

Out of the 37 patients with apparently sporadic unilateral pheochromocytomas, three patients had heterozygous missense mutations of the VHL gene. The L63P mutation of the VHL gene was identified in a 50-year-old man, whose family screening showed the presence of the same mutation in two out of the three clinically healthy brothers, whereas the mutation was absent in a clinically healthy son. The Y156C mutation was found in a 55-year-old woman, but the mutation was absent in her clinically healthy son. Finally, the R167G mutation was detected in a 20-year-old woman, whose family screening indicated the absence of mutation in her mother and two brothers. Each of these three VHL gene mutations found in our patients with apparently sporadic unilateral pheochromocytomas has been previously described as disease-causing mutations. Clinical evaluation of the three patients indicated the absence of other VHL-related tumors.

All patients with apparently sporadic unilateral pheochromocytomas were also tested for large deletions, but no loss of exons of the VHL gene was found.

\section{Discussion}

In this study, we identified disease-causing genetic abnormalities in each of the seven Hungarian VHL families and in 3 out of the 37 Hungarian patients with ASPs (8.1\%). The ten disease-causing genetic alterations detected in our study included one nonsense mutation (R161X), six missense mutations (L158V, R167Q, S80I, L63P, Y156C, and R167G), one small deletion (354_355delCT), and two large deletions of the VHL gene. In addition, one neutral VHL gene variant (P25L) was found. These genetic alterations were distributed throughout the entire VHL gene, and no hot spot or recurrent mutations were revealed (Fig. 1). Mutations resulting in truncated protein and large deletions were found only in families with VHL type 1, whereas missense mutations were associated mainly, although not exclusively with VHL type 2B and type 2C. This mutational spectrum in Hungarian VHL patients does not differ significantly from those observed in Western, Japanese, or Chinese VHL kindreds (28-30). In one of the largest series of VHL gene mutation screening, six mutation hot spots were identified and two of them (R161X and R167Q) were found in our patient cohorts (31).

Out of the ten disease-causing alterations of the VHL gene identified in our patients, all but one genetic abnormalities have already been reported in previous studies. The novel 2 bp deletion (354_355delCT) and the previously described R161X mutation, both found in VHL type 1 families in our study, result in truncated VHL proteins and, obviously, these truncated proteins may have impaired function. The two different large gene deletions detected in two VHL probands with type 1 disease may also exert a severe impact on protein function. Large gene deletions, which occurred in about $20 \%$ of patients with VHL disease in previous studies (32), usually cause VHL type 1 , but there are recent reports on Belgian and Polish 'CNS hemangioblastoma only' families $(30,33)$.

The six different missense mutations detected in our study have been previously described mainly in VHL patients with type 2 disease. The S80I mutation has been previously characterized as type 1 mutation in

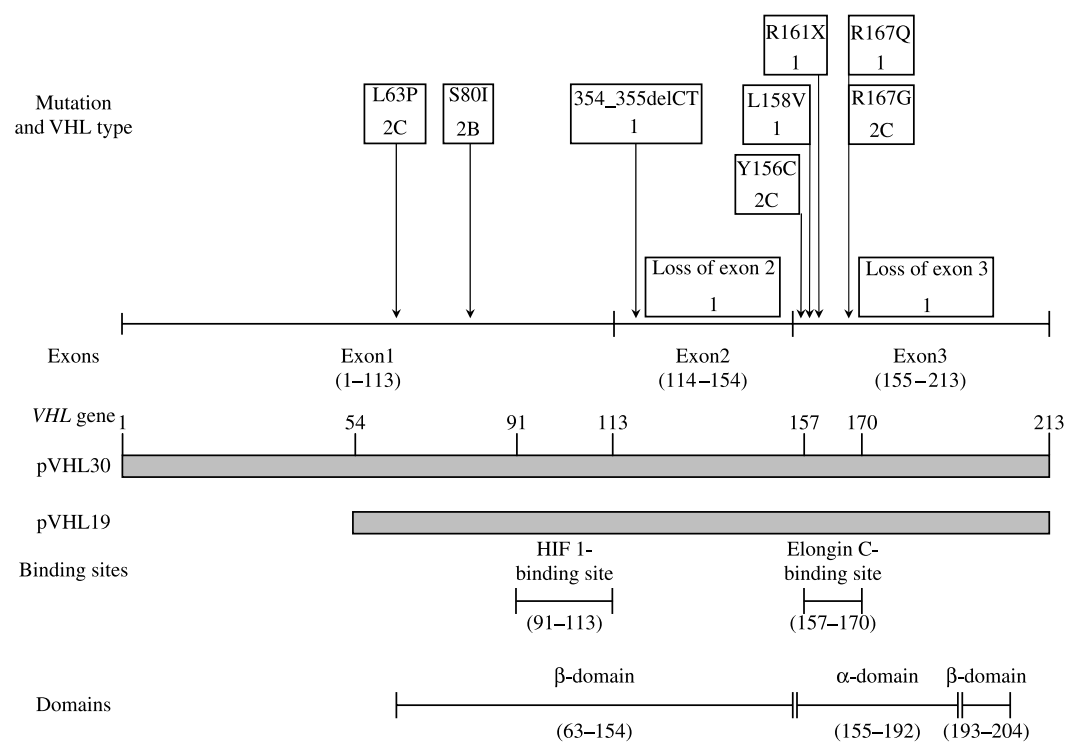

Figure 1 Localization of the $V H L$ gene mutation identified in our study. 
Western countries, but similarly to our study this mutation has been recently associated with type 2 disease in a Chinese VHL family $(34,35)$. Interestingly, in our VHL family, the S8OI mutation co-segregated with a P25L variant of the VHL gene (23). The P25L alteration has been shown to be a benign variant $(34,35)$, while the S80, together with the S68, S72, and $\mathrm{S} 65$, is a critical residue where phosphorylation of the pVHL30 by glycogen synthase kinase 3 (GSK3) occurs. These residues play an important role in the stabilization of microtubules. The GSK3 is a component of multiple-signaling pathways that are altered in human cancer, and regulation of microtubule dynamics can be critical in pVHL tumor-suppressor events (36). Lolkema and co-workers demonstrated that an additional tumorsuppressor function is linked to phosphorylation of serine residues (S33, S38, and S43) in the N-terminal acidic domain of pVHL, which is independent of the regulation of $\mathrm{HIF} 1 \alpha(37)$.

One interesting clinical finding in our study was the presence of polyglobulia without evidence of any renal lesion or other underlying disorder in a young patient with VHL type 2 disease harboring a truncating mutation (R161X), suggesting that inappropriate erythropoietin (EPO) production might play a role in this clinical abnormality. Mutations of the VHL gene have been associated with Chuvash polycythemia (CP), a rare congenital disorder without VHL-associated tumors (24, 38-43). According to our knowledge, there is no systematic review on the presence of erythrocytosis in patients with VHL disease with and without possible renal EPO overproduction; however, erythrocytosis has been reported in $5-20 \%$ of patients (5). The fundamental genetic difference between $\mathrm{CP}$ and VHL disease is that the inheritance of $\mathrm{CP}$ is autosomal recessive, while VHL disease is inherited in an autosomal dominant manner. Thus, patients with $\mathrm{CP}$ harbor germline homozygous (or compound heterozygous) mutations whereas patients with VHL disease have heterozygous VHL gene mutations. This raises questions not only on further HIF $1 \alpha$ functions or modifier genes in CP patients, but also on the significance of erythrocytosis in VHL phenotype prediction $(44,45)$.

Another interesting clinical finding was the presence of horseshoe kidney in a patient with VHL type 1 harboring the R167Q mutation. Horseshoe kidney has been extremely rarely detected in patients with VHL disease (46). It might be related to an early defect in embryonic renal development during the caudal extension of mesonephric ducts, as VHL protein has been shown to be involved in the development of the definitive metanephric kidney (47).

The usual frequency of pheochromocytomas in VHL patient cohorts is about $30 \%(48)$, which appears to be similar to our findings ( 3 out of the 7 VHL families and 5 out of the 18 clinically affected family members). The most common genetic causes of pheochromocytomas include abnormalities of the VHL (VHL syndrome), RET (multiplex endocrine neoplasia type 2), NF1, and SDH genes (familial paraganglioma/pheochromocytoma syndromes). Genetic alterations causing these hereditary syndromes may be detected in $20-30 \%$ of unselected pheochromocytoma cases (49). However, different prevalence of the $V H L$ gene mutations ranging from 0 to $11 \%$ has been documented in patients with sporadic pheochromocytomas $(14,19,50-52)$, and the relatively high frequency found in some studies (53) was considered a consequence of a founder effect (22). In our study, we showed that 3 out of the $37(8.1 \%)$ unrelated patients with histologically confirmed, sporadic unilateral pheochromocytomas had germline mutations of the VHL gene. Each patient had different mutations (L63P, Y156C, and R167G) that firmly excluded a founder effect. These mutations have been previously associated with VHL disease and have been linked to functional alterations of the VHL protein. The L63 is the first residue of the $\beta$-domain, and L63P results in a chain brake (54), while the Y156 is a critical linker between $\alpha$ - and $\beta$-domains (12). Missense R167 mutations have also been frequently associated with pheochromocytomas in VHL families (6), and mutation in this residue was present not only in a patient with sporadic pheochromocytoma (R167G) but also in a member of our VHL type 2 family (R167Q).

In conclusion, the spectrum of VHL gene abnormalities in the Hungarian population is similar to that observed in Western, Japanese, or Chinese VHL kindreds. Our findings confirm previous observations showing that germline abnormalities resulting in truncated VHL proteins cause VHL type 1, whereas missense mutations are associated mainly, although not exclusively, with VHL type 2 disease. In addition, we found that missense VHL gene mutations can be detected in $8.1 \%$ of patients with apparently sporadic unilateral pheochromocytomas, suggesting that genetic testing is useful not only in patients with VHL disease but also in those with ASPs.

\section{Declaration of interest}

The authors declare that there is no conflict of interest that could be perceived as prejudicing the impartiality of the research reported.

\section{Funding}

This work was supported by grants from the Hungarian Scientific Research Fund (OTKA K73267), the Ministry of Health (ETT 090/2006), 'Run for Cancer Research' Terry Fox Foundation, and the Regional University Center of Excellence in Environmental Industry Based on Natural Resources, Szent István University (PÁZMÁNY, RET-12/2005; BAROSS, KMKINNOV). Attila Patocs is a recipient of Janos Bolyai Research Fellowship.

\section{References}

1 Latif F, Tory K, Gnarra J, Yao M, Duh FM, Orcutt ML, Stackhouse T, Kuzmin I, Modi W, Geil L, Schmidt L, Zhou F, Li H, Chen F, Glenn G, Choyke P, Walther MM, Weng Y, Dean M, Glavac D, Richards FM, Crossey PA, Ferguson-Smith MA, Le Paslier D, Chumakov I, 
Cohen D, Chinault AC, Maher ER, Linehan WM, Zbar B \& Lerman MI. Identification of the von Hippel-Lindau disease tumor suppressor gene. Science $19932601317-1320$.

2 McGrath FP, Gibney RG, Morris DC, Owen DA \& Erb SR. Case report: multiple hepatic and pulmonary haemangioblastomas - a new manifestation of von Hippel-Lindau disease. Clinical Radiology $19924537-39$.

3 Rojiani AM, Owen DA, Berry K, Woodhurst B, Anderson FH, Scudamore $\mathrm{CH} \&$ Erb S. Hepatic hemangioblastoma. An unusual presentation in a patient with von Hippel-Lindau disease. American Journal of Surgical Pathology 199115 81-86.

4 Burns C, Levine PH, Reichman H \& Stock JL. Adrenal hemangioblastoma in von Hippel-Lindau disease as a cause of secondary erythrocytosis. American Journal of the Medical Sciences 1987293 119-121.

5 Friedrich CA. Genotype-phenotype correlation in von HippelLindau syndrome. Human Molecular Genetics 200110 763-767.

6 Maher ER, Webster AR, Richards FM, Green JS, Crossey PA, Payne SJ \& Moore AT. Phenotypic expression in von Hippel-Lindau disease: correlations with germline VHL gene mutations. Journal of Medical Genetics 199633 328-332.

7 Lonser RR, Glenn GM, Walther M, Chew EY, Libutti SK, Linehan WM \& Oldfield EH. von Hippel-Lindau disease. Lancet $20033612059-2067$.

8 Gao J, Naglich JG, Laidlaw J, Whaley JM, Seizinger BR \& Kley N. Cloning and characterization of a mouse gene with homology to the human von Hippel-Lindau disease tumor suppressor gene: implications for the potential organization of the human von Hippel-Lindau disease gene. Cancer Research 199555 743-747.

9 Blankenship C, Naglich JG, Whaley JM, Seizinger B \& Kley N. Alternate choice of initiation codon produces a biologically active product of the von Hippel-Lindau gene with tumor suppressor activity. Oncogene 199918 1529-1535.

10 Lonergan KM, Iliopoulos O, Ohh M, Kamura T, Conaway RC, Conaway JW \& Kaelin WG Jr. Regulation of hypoxia-inducible mRNAs by the von Hippel-Lindau tumor suppressor protein requires binding to complexes containing elongins $\mathrm{B} / \mathrm{C}$ and $\mathrm{Cul} 2$. Molecular and Cellular Biology 199818 732-741.

11 Schoenfeld A, Davidowitz EJ \& Burk RD. A second major native von Hippel-Lindau gene product, initiated from an internal translation start site, functions as a tumor suppressor. PNAS $1998958817-8822$.

12 Stebbins CE, Kaelin WG Jr \& Pavletich NP. Structure of the VHLElonginC-ElonginB complex: implications for VHL tumor suppressor function. Science $1999 \mathbf{2 8 4} 455-461$.

13 Beroud C, Joly D, Gallou C, Staroz F, Orfanelli MT \& Junien C. Software and database for the analysis of mutations in the VHL gene. Nucleic Acids Research 199826 256-258.

14 van der Harst E, de Krijger RR, Dinjens WN, Weeks LE, Bonjer HJ, Bruining HA, Lamberts SW \& Koper JW. Germline mutations in the vhl gene in patients presenting with phaeochromocytomas. International Journal of Cancer 199877 337-340.

15 Li C, Weber G, Ekman P, Lagercrantz J, Norlen BJ, Akerstrom G, Nordenskjold M \& Bergerheim US. Germline mutations detected in the von Hippel-Lindau disease tumor suppressor gene by Southern blot and direct genomic DNA sequencing. Human Mutation 199810 S31-S33.

16 Olschwang S, Richard S, Boisson C, Giraud S, Laurent-Puig P, Resche F \& Thomas G. Germline mutation profile of the VHL gene in von Hippel-Lindau disease and in sporadic hemangioblastoma. Human Mutation 199812 424-430.

17 Dollfus H, Massin P, Taupin P, Nemeth C, Amara S, Giraud S, Beroud C, Dureau P, Gaudric A, Landais P \& Richard S. Retinal hemangioblastoma in von Hippel-Lindau disease: a clinical and molecular study. Investigative Ophthalmology E Visual Science 2002 43 3067-3074.

18 Neumann HP \& Wiestler OD. Clustering of features of von HippelLindau syndrome: evidence for a complex genetic locus. Lancet $19913371052-1054$.

19 Neumann HP, Bausch B, McWhinney SR, Bender BU, Gimm O, Franke G, Schipper J, Klisch J, Altehoefer C, Zerres K, Januszewicz A,
Eng C, Smith WM, Munk R, Manz T, Glaesker S, Apel TW, Treier M, Reineke M, Walz MK, Hoang-Vu C, Brauckhoff M, Klein-Franke A, Klose P, Schmidt H, Maier-Woelfle M, Peczkowska M, Szmigielski C \& Eng C. Germ-line mutations in nonsyndromic pheochromocytoma. New England Journal of Medicine 2002346 1459-1466.

20 Crossey PA, Eng C, Ginalska-Malinowska M, Lennard TW, Wheeler DC, Ponder BA \& Maher ER. Molecular genetic diagnosis of von Hippel-Lindau disease in familial phaeochromocytoma. Journal of Medical Genetics 199532 885-886.

21 Woodward ER, Eng C, McMahon R, Voutilainen R, Affara NA, Ponder BA \& Maher ER. Genetic predisposition to phaeochromocytoma: analysis of candidate genes GDNF, RET and VHL. Human Molecular Genetics 19976 1051-1056.

22 Bar M, Friedman E, Jakobovitz O, Leibowitz G, Lerer I, Abeliovich D \& Gross DJ. Sporadic phaeochromocytomas are rarely associated with germline mutations in the von Hippel-Lindau and RET genes. Clinical Endocrinology 199747 707-712.

23 Patocs A, Gergics P, Balogh K, Toth M, Fazakas F, Liko I \& Racz K. Ser80Ile mutation and a concurrent Pro25Leu variant of the VHL gene in an extended Hungarian von Hippel-Lindau family. BMC Medical Genetics 2008929.

24 Pastore YD, Jelinek J, Ang S, Guan Y, Liu E, Jedlickova K, Krishnamurti L \& Prchal JT. Mutations in the VHL gene in sporadic apparently congenital polycythemia. Blood 2003101 1591-1595.

25 Ponchel F, Toomes C, Bransfield K, Leong FT, Douglas SH, Field SL, Bell SM, Combaret V, Puisieux A, Mighell AJ, Robinson PA, Inglehearn CF, Isaacs JD \& Markham AF. Real-time PCR based on SYBR-Green I fluorescence: an alternative to the TaqMan assay for a relative quantification of gene rearrangements, gene amplifications and micro gene deletions. BMC Biotechnology $2003 \mathbf{3} 18$.

26 Banks RE, Tirukonda P, Taylor C, Hornigold N, Astuti D, Cohen D, Maher ER, Stanley AJ, Harnden P, Joyce A, Knowles M \& Selby PJ. Genetic and epigenetic analysis of von Hippel-Lindau (VHL) gene alterations and relationship with clinical variables in sporadic renal cancer. Cancer Research 200666 2000-2011.

27 Shields CL, Shields JA, Barrett J \& De Potter P. Vasoproliferative tumors of the ocular fundus. Classification and clinical manifestations in 103 patients. Archives of Ophthalmology 1995113 615-623.

28 Crossey PA, Richards FM, Foster K, Green JS, Prowse A, Latif F, Lerman MI, Zbar B, Affara NA, Ferguson-Smith MA \& Maher ER. Identification of intragenic mutations in the von Hippel-Lindau disease tumour suppressor gene and correlation with disease phenotype. Human Molecular Genetics 19943 1303-1308.

29 Chen F, Kishida T, Yao M, Hustad T, Glavac D, Dean M, Gnarra JR, Orcutt ML, Duh FM, Glenn G, Green JD, Hsia YE, Lamiell JF, Li H, Wei MH, Schmidt L, Tory K, Kuzmin I, Stackhouse T, Latif F, Linehan WM, Lerman M \& Zbar B. Germline mutations in the von Hippel-Lindau disease tumor suppressor gene: correlations with phenotype. Human Mutation $1995 \mathbf{5}$ 66-75.

30 Hes F, Zewald R, Peeters T, Sijmons R, Links T, Verheij J, Matthijs G, Leguis E, Mortier G, van der Torren K, Rosman M, Lips C, Pearson P \& van der Luijt R. Genotype-phenotype correlations in families with deletions in the von Hippel-Lindau (VHL) gene. Human Genetics 2000106 425-431.

31 Zbar B, Kishida T, Chen F, Schmidt L, Maher ER, Richards FM, Crossey PA, Webster AR, Affara NA, Ferguson-Smith MA, Brauch H, Glavac D, Neumann HP, Tisherman S, Mulvihill JJ, Gross DJ, Shuin T, Whaley J, Seizinger B, Kley N, Olschwang S, Boisson C, Richard S, Lips CH \& Lerman M. Germline mutations in the von Hippel-Lindau disease (VHL) gene in families from North America, Europe, and Japan. Human Mutation 19968 348-357.

32 Casarin A, Martella M, Polli R, Leonardi E, Anesi L \& Murgia A. Molecular characterization of large deletions in the von HippelLindau (VHL) gene by quantitative real-time PCR: the hypothesis of an alu-mediated mechanism underlying VHL gene rearrangements. Molecular Diagnosis and Therapy 200610 243-249.

33 Cybulski C, Krzystolik K, Murgia A, Gorski B, Debniak T, Jakubowska A, Martella M, Kurzawski G, Prost M, Kojder I, Limon J, Nowacki P, Sagan L, Bialas B, Kaluza J, Zdunek M, 
Omulecka A, Jaskolski D, Kostyk E, Koraszewska-Matuszewska B, Haus O, Janiszewska H, Pecold K, Starzycka M, Slomski R, Cwirko M, Sikorski A, Gliniewicz B, Cyrylowski L, Fiszer-Maliszewska L, Gronwald J, Toloczko-Grabarek A, Zajaczek S \& Lubinski J. Germline mutations in the von Hippel-Lindau (VHL) gene in patients from Poland: disease presentation in patients with deletions of the entire VHL gene. Journal of Medical Genetics 200239 E38.

34 Rothberg PG, Bradley JF, Baker DW \& Huelsman KM. Is the P25L a "real" VHL mutation? Molecular Diagnosis \& Therapy 2001 6 49-54.

35 Pettman RK, Crowley A, Riddell C \& Ludman MD. VHL P25L is not a pathogenic von Hippel-Lindau mutation: a family study. Molecular Diagnosis and Therapy 200610 239-242.

36 Hergovich A, Lisztwan J, Thoma CR, Wirbelauer C, Barry RE \& Krek W. Priming-dependent phosphorylation and regulation of the tumor suppressor pVHL by glycogen synthase kinase 3. Molecular and Cellular Biology 200626 5784-5796.

37 Lolkema MP, Gervais ML, Snijckers CM, Hill RP, Giles RH, Voest EE \& Ohh M. Tumor suppression by the von Hippel-Lindau protein requires phosphorylation of the acidic domain. Journal of Biological Chemistry $2005 \mathbf{2 8 0} 22205-22211$.

38 Ang SO, Chen H, Gordeuk VR, Sergueeva AI, Polyakova LA, Miasnikova GY, Kralovics R, Stockton DW \& Prchal JT. Endemic polycythemia in Russia: mutation in the VHL gene. Blood Cells, Molecules $\mathcal{E}$ Diseases 200228 57-62.

39 Wiesener MS, Seyfarth M, Warnecke C, Jurgensen JS, Rosenberger C, Morgan NV, Maher ER, Frei U \& Eckardt KU. Paraneoplastic erythrocytosis associated with an inactivating point mutation of the von Hippel-Lindau gene in a renal cell carcinoma. Blood $2002993562-3565$.

40 Pastore Y, Jedlickova K, Guan Y, Liu E, Fahner J, Hasle H, Prchal JF \& Prchal JT. Mutations of von Hippel-Lindau tumor-suppressor gene and congenital polycythemia. American Journal of Human Genetics $200373412-419$.

41 Cario H, Schwarz K, Jorch N, Kyank U, Petrides PE, Schneider DT, Uhle R, Debatin KM \& Kohne E. Mutations in the von HippelLindau (VHL) tumor suppressor gene and VHL-haplotype analysis in patients with presumable congenital erythrocytosis. Haematologica 200590 19-24.

42 Bento MC, Chang KT, Guan Y, Liu E, Caldas G, Gatti RA \& Prchal JT. Congenital polycythemia with homozygous and heterozygous mutations of von Hippel-Lindau gene: five new Caucasian patients. Haematologica 200590 128-129.

43 Randi ML, Murgia A, Putti MC, Martella M, Casarin A, Opocher G \& Fabris F. Low frequency of VHL gene mutations in young individuals with polycythemia and high serum erythropoietin. Haematologica 200590 689-691.
44 Kaelin WG Jr. The von Hippel-Lindau tumor suppressor gene and kidney cancer. Clinical Cancer Research 2004106290 -6295S.

45 Perrotta S, Nobili B, Ferraro M, Migliaccio C, Borriello A, Cucciolla V, Martinelli V, Rossi F, Punzo F, Cirillo P, Parisi G, Zappia V, Rotoli B \& Ragione FD. Von Hippel-Lindau-dependent polycythemia is endemic on the island of Ischia: identification of a novel cluster. Blood $2006 \mathbf{1 0 7} 514-519$.

46 Crawford ED, Henning DC \& Wendel RG. Renal cell carcinoma in a horseshoe kidney associated with von Hippel-Lindau disease. Journal of Urology $1979121677-678$.

47 Richards FM, Schofield PN, Fleming S \& Maher ER. Expression of the von Hippel-Lindau disease tumour suppressor gene during human embryogenesis. Human Molecular Genetics $1996 \mathbf{5}$ 639-644.

48 Koch CA, Vortmeyer AO, Zhuang Z, Brouwers FM \& Pacak K. New insights into the genetics of familial chromaffin cell tumors. Annals of the New York Academy of Sciences 2002 970 11-28.

49 Maher ER \& Eng C. The pressure rises: update on the genetics of phaeochromocytoma. Human Molecular Genetics $2002 \mathbf{1 1}$ 2347-2354.

50 Lenders JW, Eisenhofer G, Mannelli M \& Pacak K. Phaeochromocytoma. Lancet 2005366 665-675.

51 Korpershoek E, Van Nederveen FH, Dannenberg H, Petri BJ, Komminoth P, Perren A, Lenders JW, Verhofstad AA, De Herder WW, De Krijger RR \& Dinjens WN. Genetic analyses of apparently sporadic pheochromocytomas: the Rotterdam experience. Annals of the New York Academy of Sciences 2006 1073 138-148.

52 Pacak K, Eisenhofer G, Ahlman H, Bornstein SR, GimenezRoqueplo AP, Grossman AB, Kimura N, Mannelli M, McNicol AM \& Tischler AS. Pheochromocytoma: recommendations for clinical practice from the First International Symposium. October 2005. Nature Clinical Practice. Endocrinology \& Metabolism 20073 92-102.

53 Neumann HP, Berger DP, Sigmund G, Blum U, Schmidt D, Parmer RJ, Volk B \& Kirste G. Pheochromocytomas, multiple endocrine neoplasia type 2, and von Hippel-Lindau disease. New England Journal of Medicine 1993329 1531-1538.

54 Miller F, Kentsis A, Osman R \& Pan ZQ. Inactivation of VHL by tumorigenic mutations that disrupt dynamic coupling of the pVHL.hypoxia-inducible transcription factor-1alpha complex. Journal of Biological Chemistry 2005280 7985-7996.

Received 14 June 2009

Accepted 24 June 2009 